\title{
THE ENEMY - A PARTISAN HYMNBOOK: CRITICAL NOTES ON MEMORY, MUSIC, AND THE MAKING OF A DOCUMENTARY FILM
}

\section{FEDERICO SPINETTI}

\begin{abstract}
In the following pages I provide a study guide and a critical discussion of my documentary film The Enemy - A Partisan Hymnbook (2015). In the process, my reflexive and interpretive remarks are meant to bear on issues of more general interest for the study of music, memory and conflict, and for the theory and practice of audio-visual media particularly in ethnomusicology.
\end{abstract}

Key words: audiovisual ethnomusicology; memory; WWII Resistance; Italy; popular music.

The cinema is a realist art: but it remains that this realist art has progressed only by means of straining against its own principle, through forceful doses of unrealism.

(Chion, 1994, 54)

... the use of the camera feels more than anything like playing a musical instrument.

(MacDougall, 1995, 240)

Because there comes a point when one must choose on which side to stand, or at any rate from what position to see the events.

(Carrère, 2011, 231) ${ }^{1}$

\section{An Encounter}

"And I have seen the unknown dead, the fascist dead. They are the ones who awakened me. If a stranger, an enemy, becomes similar to us by dying, if we stop afraid to walk past his corpse, it means that even defeated the enemy is someone, and that after spilling his blood we must placate him, give a voice to this blood, and justify those who shed it. To look at certain deaths is humiliating. They are no longer just someone else's concern; it is not by chance that we find ourselves having to face them. It seems that the same destiny that laid those corpses on the ground now forces us to stare at them, to fill our eyes with them. This is not fear, nor the usual cowardice. We feel humiliated because we realize that we could be there in the place of the dead. There would be no difference. And if we live, we owe it to that blood-stained corpse. This is why every war is a civil war. Those who fell resemble those who stand, and demand an explanation from

1 Translation from the original French by the author. 
them. ... I do not think that it can come to an end. Now that I have seen what the civil war is, should it finish, I know that all should ask themselves: how do we deal with the dead? Why did they die? I would not know how to answer, at least not now. And no one else seems to know either. Perhaps only the dead know, and only for them the war is really over." (Pavese, 2008, 122-123) ${ }^{2}$

Written in the immediate aftermath of the Second World War and the Italian civil war (1943-45), these lines from Cesare Pavese's 1948 book La casa in collina form the underlying motif of my work as director of the documentary film The EnemyA Partisan Hymnbook (2015). ${ }^{3}$ They also played a key role in my encounter with the film's protagonist, Massimo Zamboni, and in the birth of our concerted idea of making this film. I met and interviewed Zamboni for the first time in 2013 in Bologna as part of my ongoing research into the memorialization of the Second World War antifascist Resistance (Resistenza) in contemporary Italian popular music. Since the late 1980s up until today, a great number of musicians have addressed and reinterpreted the legacy of the Resistenza - understood primarily as the armed struggle of the partisans against both the Nazi-German occupying army and the Italian fascists of Mussolini's Social Republic - and have geared this toward an interrogation of current societal issues. Among the prominent exponents of this movement were the seminal punk band CCCP (1982-1990) and their equally influential sequel CSI (1992-2002). Massimo Zamboni was the co-founder, guitarist and music composer of both. On our first meeting, Massimo and I engaged in an absorbing dialogue and realized that we shared many ideas and concerns regarding the memory of the Resistenza. We both had given much thought to Pavese's words and reckoned that they provided a reflection of unresolved complexity and great actuality, which was worth digging into.

I was already planning to make a film on my research topic and had been trying out ideas with the Italian independent film company Lab80film - with whom I had previously made two films ${ }^{4}$ - but was scrambling to find a narrative focus. Massimo was completing a book about a most intriguing story: he - an artist who has been consistently associated with the left, antifascism and the Resistenza in his career - had uncovered a troublesome chapter in his family's past: his maternal grandfather was a committed fascist during Mussolini's regime, and was shot dead in ambush by the partisans in 1944. Against the reticence of his relatives, Massimo researched and unpacked his family's history,

2 Translation from the original Italian by the author.

3 The original Italian title is Il Nemico - un breviario partigiano, 80 minutes, English subtitles.

4 Zurkhaneh - The House of Strength. Music and Martial Arts of Iran (2011); And The Mountains Float Up Like Feathers (2013). 
his grandfather's life, and that of his assailants. ${ }^{5}$ It seemed to Massimo and me that joining forces on a film project would allow us to put to productive use our intellectual, political and creative commitments. The subject of Massimo's book became the backbone of The Enemy, which I envisaged as a narrative nonfiction film focusing on Zamboni's portrait, his music trajectory and the memory of the Resistenza seen through the prism of his experience and research.

\section{A collaborative film}

The Enemy was a collaborative venture on at least two fronts. First, I (as director) shared key responsibilities with Andrea Zanoli (director of photography) and Alberto Valtellina (producer and chief editor) of Lab80film. Our division of work was in fact quite fluctuating: I contributed to the shooting and the editing as much as Andrea and Alberto injected important ideas into the narrative design. Second, The Enemy involved close collaboration with the film's participants, primarily the protagonist. It was in important ways a subject-generated film. Perhaps in contrast to other collaborative ethnographic and documentary films, I did not work with "people who lead lives that are different from those traditionally in control of the means for imaging the world" (Ruby, 1991, 50). Massimo and the other CSI members who later joined the project are artists of nationwide renown conversant with media representations and experienced in exercising control over their public image. They had access to music distribution channels of a far larger scale than I had ever contemplated for my work - a situation that widened the dissemination prospects of the film and factored its completion into their professional agenda. Thus my position here was as much about relinquishing power as a filmmaker - for example, by accommodating the participants' selective input on what or what not to film as an ethical and methodological principle of collaborative ethnography - as it was about acquiring power, making sure that I was on an equal footing with the musicians as to decisions regarding the circulation and commercial reification of the film.

An equally crucial aspect of our collaboration, Massimo and I deemed it essential that the centrality of his subjectivity in matters of content (as protagonist and storyteller) be staged in dialogue with my authorial voice in matters of narrative and cinematic choices. But our relationship also entailed mutual influences across filmmaker's and participant's positions, such that the line between authorial construction and subject-generated content became oftentimes porous. An instance of this is the reunion of CSI depicted in the film. Fifteen years after their breakup, Massimo saw the film project, at that point

5 Zamboni's book L'eco di uno sparo (2015) was published around the same time of the film's release by the publisher Einaudi in their prestigious series Supercoralli. 
already underway, as an opportunity to call back the other band members to engage once again with the memory of the Resistenza and write new songs on this theme. He invited them to take part in the film and suggested a theatre in the town of Gualtieri as a location for filming their compositional process. The band had previously resumed touring under the name of Ex-CSI, with Angela Baraldi substituting former singer Giovanni Lindo Ferretti, but this was the first time since their breakup that they would come together for a new music project. For the occasion they renamed themselves Post-CSI. As a result, the film became part of a larger publication venture, named Breviario Partigiano (Partisan Hymnbook), which included an album based on the film's soundtrack and a limited-edition pocketbook in which numerous Italian intellectuals and artists were invited to contribute their thoughts on the Resistenza.

The band reunion became a central motif of the film, representing an important subject-generated input to the narrative construction. But, in turn, it was the film project itself that had occasioned Massimo's initiative to reunite the band. The film, much as participant observation, impacted the participants' life-world and set out to represent an event that it partly contributed to create. This situation posed issues that had to do with documentary ethics as well as with the representational status of the film. Rather than putting myself onscreen or resorting to exposition - which I felt would detract from the narrative focus on Massimo's powerful story -- I opted for disclosing the film's intervention in the life-world portrayed by underlining my authorial presence through formal means, notably the use of discernibly staged scenes, as well as scripted references to the Partisan Hymnbook project in Massimo's narration. Also, the use of highly interactive, conversational camerawork encouraged not only the recurrent acknowledgment of the camera by Post-CSI, but also their performance for the benefit of the camera. In many instances of the film, it can be said, in the words of Michael Kirkby, that "they were acting their own emotions and beliefs." $(1987,7)$ This combination of authored design and participant's conscious selfdisplay proved to be a productive avenue to establish common ground toward a concerted, plural statement. 


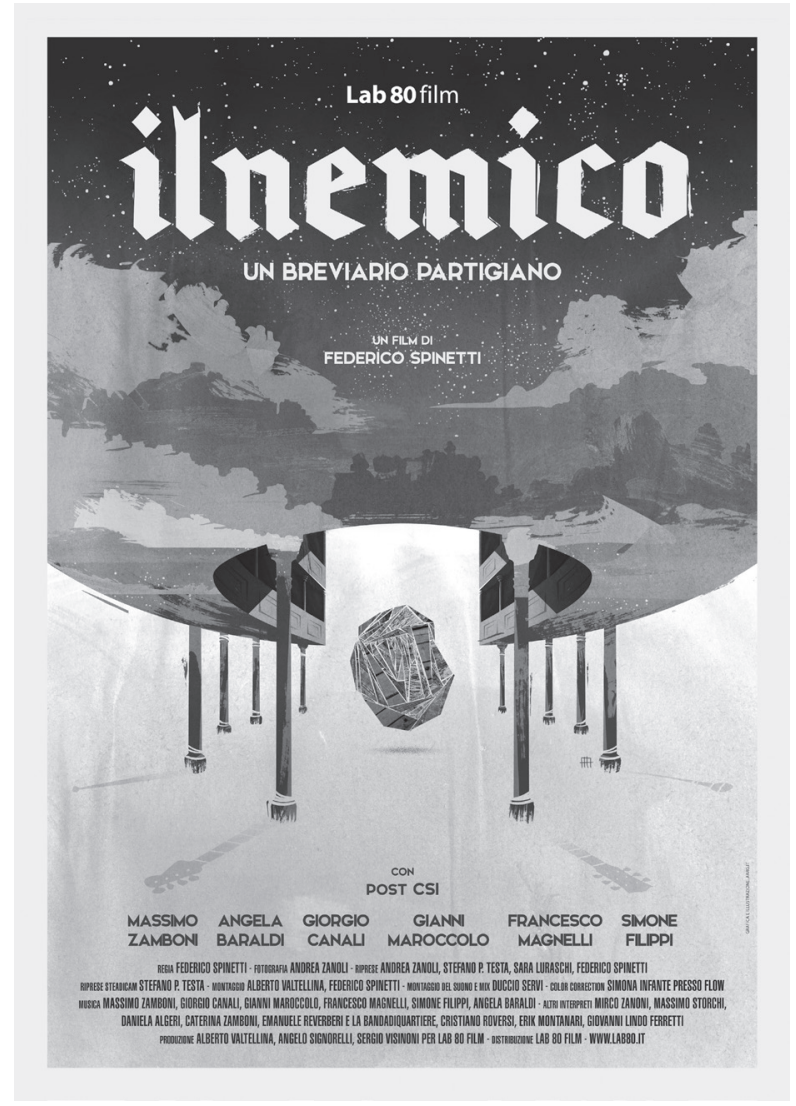

Figure 1. The Italian version of the film poster. (Rossi, 2015).

\section{A STRUGGLE FOR MEMORY}

Working with renowned musicians such as Post-CSI afforded prospects of high visibility to the film, especially in Italy, and made it realistic to target, in addition to an academic audience, a large general public. I should also remark that researching the musical memorializations of the Resistenza was, for me, an existentially and politically salient endeavour. After years of research particularly in Central Asia and Iran, I was now coming full circle and addressing the very social and cultural milieu that was central to my own formation as a young adult in Italy, both politically (as a radical leftist and antifascist), and musically (as a rock enthusiast and musician who, like many others in the Italian student culture of the 1990s, looked up to CSI as one of their points of reference). 
These factors shaped my approach to the film project, notably as a form of engaged applied research (Pettan and Titon, 2015) that could contribute to the ongoing public debate about the Resistenza in Italy. In particular, I - and Massimo with me - have conceived of the film as a part of the movement of antifascist intellectuals, artists, activists and civic organizations that, in the last three decades or so, have invested considerable cultural work in the cultivation of the Resistenza legacy. Though undertaken with diverse modalities and emphases, these efforts have shared a concern with salvaging the memory of the Resistenza from the breakdown of the Cold War political framework and with asserting its contemporary relevance. At the same time, they have recast it in terms that are rejuvenating with respect to the discursive paradigms typical of that framework, where the Resistenza was canonized in institutional representations as the founding myth of the Italian Republic, and absorbed within the contending and self-legitimating narratives of political parties (primarily the Italian Communist Party and the Christian Democracy party). (Focardi, 2005)

In the course of the 1990s we witness an increasing de-territorialization of antifascist and Resistenza discourse, moving away from traditional party politics toward independent civic activism, away from commemorative magniloquence toward a multiplicity of new vocabularies and interpretive renovations. Those momentous twenty months (September 1943-April 1945) of rebellion against the Nazi German occupation and the newly reconstituted Italian fascist regime have been seen as a unique episode in national history, one that exemplarily encapsulates the perceived hinges of a contemporary antifascist civic morality: grassroots and subaltern self-reliance, utopian desire, refusal of authority and "voluntary servitude" (Hardt and Negri, 2000, 204), experimentalism in egalitarian coalitional efforts in matters of social, intercultural, gender and work relations. (see Romitelli, 2015; Hardt and Negri, 2000, in particular pp. 157-159, 204-211)

The memory of the Resistenza has been all the more persuasive because the struggle was not only waged against an inimical "outside" (the foreign occupation), but also against an "inner enemy" (Bermani, 2003), that is, the Italian fascists and the authoritarian social and power system within which the partisans themselves, especially the numerous youths within their ranks, were raised and socialized. As such, the Resistenza legacy has provided an ethical-political point of reference, a resource for the imagination, and a discursive framework able to sustain and galvanize a variety of antagonist positions in the present, ranging from antiracist and anti-capitalist militancy, to criticality vis-à-vis neoliberal inequalities, global dispossession and rampant xenophobia, to active endeavours of participatory citizenship. Of equal importance has been a preoccupation with the process of rehabilitation of fascism and its memory, which, since the early 1990s, has gained currency in the Italian public space. This has been accompanied by a political 
legitimization of far-right and neofascist movements, as well as by historiographic revisionism promoting not only a devaluation, if not outright demonization, of the Resistenza, but also a sugar-coated, let alone celebratory, representation of Italian colonialism and authoritarianism. (see Mattioli, 2010)

In this context, The Enemy aims to speak to that stream of contemporary leftist Italian historiography, which, in the last three decades, has addressed with novel critical intent the Resistenza and the formation of post-war antifascist memory. ${ }^{6}$ Here, the film calls attention to the important contribution of musicians and musical life to memory making, a contribution that has been apparent to many antifascist activists and sympathizers, but has remained almost invisible in the discussions of critical scholars. ${ }^{7}$

Furthermore, the film aims to tackle an issue that has proven quite thorny, not only in a broad national debate but also within antifascist discourse itself, namely the status of private and collective memories of the civil war, and their relationship. In a nutshell, the underlying contention of the film is that the recognition of private and family memories that involve the loss of the fascist dead need not clash with a firm antifascist stance. This proposition relies on a re-humanization of the enemy and an affirmation of the grieveability of all life. (see Butler 2004; 2009) It calls upon the antifascist front to re-appropriate and own the violent deaths of the civil war, not only those suffered at the hands of the enemy but also those inflicted on the enemy. This ultimately urges antifascism to interrogate the role of violence in emancipatory struggle and to reclaim the reasons for its exercise in the partisan experience - a topic entertained uncomfortably in antifascist discourse, particularly when it comes to the killings perpetrated immediately after the end of the war. (see, among others, Storchi, 2007) The film highlights the contentious nature of this last point by bringing into focus different understandings of the legitimacy of violence, epitomized, not least musically, by Massimo Zamboni and Giorgio Canali (see Sequences 12-14 below).

In this sense the film addresses Cesare Pavese's reflection (quoted at the beginning of this article) through the prism of Massimo's experience. My intention was to tacitly clothe this experience with the significance of a metaphor. Massimo's unremitting and painful investigation into his family's past may stand for a similar possibility, for Italian society at large, to come to terms with its own history and sorrows. Massimo's rejection of his family's political

6 The contributions to this field of inquiry - whose voice has often percolated beyond the scholarly into a broader public domain - are too numerous to be listed here. Suffice it to mention Pavone (1991) as the study that, perhaps more than others, has represented the seminal impetus for this novel approach.

7 This applies also to some of the most attentive commentators, such as Luzzatto (2004) or Romitelli (2007; 2015) 
background further indicates that harbouring private memories of and affective links to individuals who subscribed to authoritarian projects does not necessarily translate into a political affiliation of the same sign. Here the film's argument admittedly performs a tightrope walk. The mourning of the fascist dead has often been used by the far right for its political legitimation and for recruitment, in this way effecting a confusion between human recognition and political affiliation, between private and public memories. Massimo's story is there to testify that this confusion can be discarded. The politicization of the personal elaborated in the film amounts in our intentions to a different proposition from the one increasingly entertained in Italian public discourse, which purports the ideas of national reconciliation, of 'shared memories' across political fronts, and of the moral equivalence between partisan and fascist fighters. To carve a space for fascist family memories within antifascist discourse is not an act of apology or remittance of the responsibilities of fascism. On the contrary, it can provide an obstacle to the crystallization of those memories into neofascist political views, and contribute to the expansive potential of antifascism.

The reception history of the film I can testify to - including reviews and Q\&As at public screenings - showed diverse responses to the film's political propositions. These triggered discussions, particularly within antifascist circles, that ranged from fervent interest to outright suspicion, demonstrating the controversial and thus constructive nature of the themes addressed.

\section{Music, memory, film}

My work on The Enemy was guided by the understanding that documentary filmmaking can be a form of research, one that engages as much with affective and sensuous knowledge as with analytical and discursive knowledge. (see for instance MacDougall, 1995, 17-18; 1998; Grimshaw and Ravetz, 2009, 113-136) Accordingly, I intended to contribute to a growing interest in ethnomusicological and popular music scholarship in the study of music, conflict and violence (see, among others, Pettan, 1998; Araújo, 2006; O'Connell and Castelo-Branco, 2010; MacDonald, 2009; Johnson and Cloonan, 2009), through a focus on the politics of memory making and the contribution of music to the construction of historical narratives. Not unlike other studies of music and memory (see in particular Shelemay, 1998; Bithell, 2006; Baker, 2009; Momcilovic, 2011; Hofman, 2015; Bennett and Janssen, 2016), I also aimed to address the field of memory studies, specifically the one concerned with cultural and collective memories (see for example Connerton, 1989; Erll and Nünning, 2008; Assmann, 2009) and therein call attention to the often overlooked role of music making in memory practices. I was particularly interested in the notion that memory - and therefore musical memorialization - is constructed through processes of mediation and 
remediation of experiences and of their attendant memorial inscriptions. (see Erll and Rigney, 2009; Whitehead, 2009: 39-50) The Enemy pays particular attention to these "medial frameworks" (Erll and Rigney, 2009, 2) and makes the mechanisms of remediation visible by exploring the inter-textual tapestry at work in the construction of the Resistenza memory across music, song lyrics, photographs, moving pictures, literature and historiography. It was important for me that the film itself be positioned reflexively as a memorial device and as part of the very process of mediation of memory it represents.

Despite notable exceptions (see for instance Zemp, 1988; Baily, 1989 and 2009; Cámara de Landa et al., 2016) audio-visual practices in ethnomusicology remain conspicuously under-theorized. Discussions have tended to be fairly prescriptive, possibly in response to a legitimate preoccupation with securing for the discipline an ethical and epistemological foundation that would be distinctive with respect to dominant media and imaging practices - in this, paralleling similar concerns in visual anthropology. While I share this understanding of documentary film as a communicative code whose representational and stylistic procedures are imbued with ideological and cultural biases and therefore call for critical awareness, ${ }^{8}$ my purpose in The Enemy was to take full advantage of the medium and produce a cinematic construction that would tap into the practice and theory of audio-visual ethnomusicology as much as that of independent and art documentary filmmaking. As I will illustrate in more detail below, The Enemy employs a combination of representational strategies that are deepseated in the ethnographic tradition and that have been codified by film critic Bill Nichols (2001: 105-130), with reference to a broader documentary film practice, as the "modes of representation" of exposition (i.e. direct address to the viewer), reflexivity (i.e. disclosure of cinematic artifice), participation (i.e. interaction between filmmaker and participants), and observation (i.e. attendance to the flow of lived experience). ${ }^{9}$ Further, the film adopts at different points the expressionist and affective cinematic logic that Nichols associates with his poetic and performative modes $(2001,102-105 ; 130-137)$. I found this approach particularly congenial for both exploring the analogies and triggering cinematically the synergies between memory, music, and film. These all work importantly by association, affect and embodiment. They all have to do as much with structured collective codes as with lived subjective experience, as much with the constative utterance of factual information or the expression of pre-existing

8 For a classic and still relevant discussion in ethnomusicology, see Feld, 1976.

9 It is known that the observational mode in particular has been understood in quite different ways across critical discourses. Nichols' characterization of it as fundamentally detached and voyeuristic contrasts sharply with the more reflexive and interactive understandings of observational cinema elaborated in anthropology. For a comprehensive discussion see Grimshaw and Ravetz, 2009. 
knowledge as with the performative creativity of exhortation, imagination, possibility, and desire. (see Austin, 1999) ${ }^{10}$ In order to tap into these affective and imaginative dimensions, The Enemy makes use of cinematic devices such as aestheticization, stylization, evocative accentuation and poetic allusion - a set of practices that Keith Beattie has encapsulated in the notion of "documentary display" as a cinematic function that maximizes "affective bonds", "spectatorial attraction" and pleasure $(2008,4-6,29) .{ }^{11}$ It thus navigates a fine line between ethnography and cinematic invention, between realism and hyperbole. It does so, for example, by evoking sonically and musically the intensity of inner experience inhabiting Massimo's memory process ${ }^{12}$, or, reversely, by giving visual form to the associative imagination that is part and parcel of the experience of (live) music - in this sense fracturing a common visual practice in ethnomusicology that identifies in the musicians and event participants all there is to be seen and represented of a music performance. In this way the film attempts to access levels of experience outside the literality of action and to exploit the potential for evocation and affective knowledge of documentary representation. At the same time, it purposefully resists the bombastic and manipulative register that I find in much mainstream documentary. In this respect, if the film departs, as it does, from a strictly observational approach in matter of representational choices, it is nonetheless poised on a broad observational and ethnographic sensibility, one that affords interpretive openness, and that is based on knowledge generated from the participants' life-world and understandings.

\section{Production and release}

The film was produced by Lab80film. Upon joining in, Post-CSI launched a crowdfunding campaign on the online platform Musicraiser, whose revenues went mostly into the production of the music album and the packaging of the CD-DVD set and pocketbook. The film benefited from the logistical and moral support of a number of associations and institutes. ${ }^{13}$ The CD-DVD set was

${ }^{10}$ For memory as implicated in desire see for example Whitehead, 2009, 49. On iconic and indexical processes in music semiotics see, for instance, Turino, 1999. On sound and affect, see Thompson and Biddle, 2013.

${ }^{11}$ While Beattie conceptualizes "display" predominantly in visual terms, a fully audio-visual perspective, including sound and music, must be emphasized here.

${ }^{12}$ Germane to this approach is MacDougall's remark that "memory offers film its ultimate problem: how to represent the mind's landscape, whose images and sequential logic are always hidden from view." $(1992,29)$

${ }^{13}$ Especially ISTORECO (Reggio Emilia Institute for the Resistance and Contemporary History), the Istituto Alcide Cervi, ANPI (National Association of Italian Partisans) of Correggio, and the Associazione Teatro Sociale of Gualtieri. 
released and distributed by Universal Music Italy. ${ }^{14} \mathrm{~A}$ limited edition including the pocketbook was reserved for crowdfunding contributors and also made available at Post-CSI concerts. The film alone was distributed by Lab80film in the independent cinema theatre circuit in Italy, at international documentary film festivals and for TV broadcast. ${ }^{15}$ Additionally, screenings were held at several Resistenza-related public events organized by civic associations in Italy, and at international academic symposia. In Italy the film has received extensive media coverage including highlights and reviews in the local and national press, as well as in specialized cinema magazines. Several interviews with Massimo or me were broadcast on radio stations, and I appeared twice in interview on the Italian national TV channel RAI Uno.

\section{Shooting and editing}

Shooting took place in several sessions over a 22-month period, from April 2013 to January 2015. Typically Andrea Zanoli, Alberto Valtellina and I would make the $150 \mathrm{~km}$-drive from Bergamo, where Lab80film is based, to Reggio Emilia and spend two or three days at a time there with Massimo. Our work method was based on scheduling dedicated time that could be used productively toward the advancement of the film - exploring locations in the Reggio Emilia area related to Massimo's story; capturing interviews, landscapes and action scenes. Most of the shooting on these occasions was done with one HD camera and sound was recorded with a boompole or clip-on microphone. I made a number of additional trips to meet Massimo and engage in extensive briefing about his book, his research, and the progress of the film. Our work here resonated very much with the sort of collaboration that, in Sarah Elder's words, "provides a space for filmmakers to learn to pose questions they originally do not know to ask, a place where film subjects select the fragments of their reality they deem significant to document, and a moral place where subjects and image makers can mediate their own representation." $(1995,94)$ A somewhat larger crew of four to five people worked on shooting sessions that required the handling of dollies and tracks and/ or of multiple cameras. These included live concert performances and the scenes set in the Gualtieri Theatre. The latter were shot over three consecutive days in which Post-CSI and the film crew shut themselves in the theatre from morning to night so as to attend to the composition of the song Il nemico (The Enemy).

While the shooting process was strongly informed by Massimo's and PostCSI's input, the editing was done entirely by Alberto Valtellina and me over

\footnotetext{
${ }^{14}$ Post-CSI, 2015.

${ }^{15}$ A number of ethical issues arose out of the relationship with major distribution, of which the most salient is discussed below apropos of Sequence 12.
} 
two months of high-intensity work. The final cut utilizes about a tenth of the overall captured footage. Rather than a limitation, the selection of footage in the postproduction was a decisive factor in shaping the sense of purpose of the project and distilling the specific contribution to memory making that I was aiming at. I remember the trepidation with which I submitted the edited film to Massimo at our first private screening. On reflection it was not surprising that he approved of it in its entirety. It had been clear all along that we had reached a shared understanding about how to combine ethical and creative practices in the filmmaking process. And also that it was as important for me that he is represented respectfully and fairly, as it was for him that his experience be authored and reframed by me. ${ }^{16}$

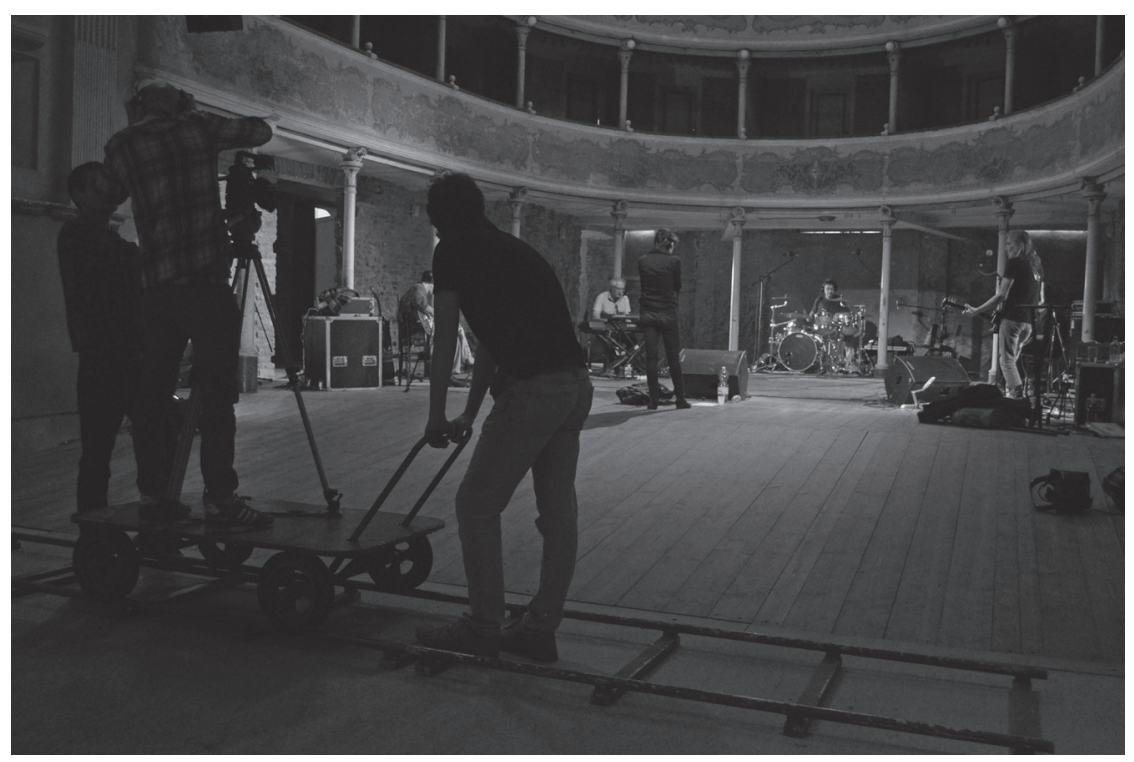

Figure 2. Filming Post-CSI at work in the Gualtieri Theatre. (Fantetti, 2014)

\section{The film's structure}

In this section I provide a description and examination of the film's layout. I refer to "scenes" as clusters of cinematic materials that usually maintain a recognizable unity of time and space, and to "sequences" as larger sections, generally made of multiple scenes, which operate as fairly distinct narrative units and explore a specific topic or situation. ${ }^{17}$ Sequences are further grouped into chapters, which provide the thematic building blocks of the narrative.

\footnotetext{
${ }^{16}$ See Elder, 1995, 96.

${ }^{17}$ See Barbash and Taylor, 1997, 123.
} 
Sequence 1 (00:00-03:13) opens with a night shot of a roadside partisan memorial stone. Next, a black screen crossfades into a series of jump cuts as the handheld camera moves along a country path, in a bleak winter morning on the characteristic flatland of the Po valley. Opening credits run throughout. The camera lingers on a tilted cross, planted in the ground, and a torn Italian flag waving on its pole. After the diegetic sound of the opening shot, this scene features the pit-music ${ }^{18}$ bass-guitar line of the CSI Resistenza-themed song Linea Gotica (Gothic Line), recorded solo upon my request by CSI bass-player Gianni Maroccolo. As the music fades out, the camera cuts to a side view of the film's protagonist, Massimo Zamboni. He sits in front of a computer screen displaying the cover of his book L'Eco di uno sparo (The Echo of a Gunshot). His hands leaf through a typed manuscript as he talks about his writing process. Finally he folds up the manuscript and says: "It's been six years of research." Pit music kicks in - it is the instrumental opening of Zamboni's song Che farai (What will you do) - as the mounted camera pans to follow a car leaving a country mansion. Massimo's voiceover relates how he began his book research on his family history during the war and the Resistenza, specifically tracing what, in that history, led up to a gunshot. The pit music rises again and a long take of the car driving down a country road features further opening credits and the title text. A series of cuts within the car show Massimo driving while the hills and the Po valley roll by. The camera pans out to capture the city of Reggio Emilia signpost. In the closing shot Massimo's car enters a parking lot, while the pit music fades out.

I conceived of the opening sequence as a rather elusive preamble to some of the thematic cores of the film. It is intentionally made to play with the "degree of communicativeness" (Nichols, 1991, 123) of the filmic text, by giving out pieces of information while withholding others with a view to create expectation. Rural landscapes of Reggio Emilia are presented as key locations in the film, but their importance as "signs of memory" (MacDougall, 1992) is yet to be evinced. The cross in the opening scene, as a metonym of death, evokes a central theme in the film, but its identity and location are not yet revealed. Similarly, while the film's protagonist is introduced, the nature of his research efforts is only vaguely mentioned. In this way, a characteristic of the film's narrative is established, that of a gradual disclosure of Massimo's research and existential trajectory. The opening sequence, moreover, sets the stage for three primary representational approaches of the film: observational and participatory encounter of the camera with Massimo as a mode of elicitation of his testimony; cinematic stylization as a register of performative aesthetics and poetic evocation; readily-identifiable staging of (some) scenes as both a reflexive and narrative device.

${ }^{18}$ Here and throughout I refer to different typologies of sound in film using the terminology codified by Michel Chion (1994). 
Sequences 2 to 5. This chapter traces the musical history of the band CCCP and its later reincarnations as CSI and Post-CSI from the standpoint of Massimo Zamboni. It provides a background to the protagonist's profile and the compositional process to be explored later in the film. My concern here was to deliver a content that would be intriguing for audiences already familiar with $C C C P$ and its successors, and sufficiently informative for (primarily international) audiences not necessarily acquainted with them.

Sequence 2 (3:13-06:16) opens with a scene that is closely related to the ending of the preceding sequence: the camera follows Massimo entering a postal office and picking up a package. This scene was engineered to some extent: since I wanted to capture Massimo's first reactions to the content of the package avoiding the affectation of a re-enactment, Massimo and I agreed on a specific date for filming the package delivery- a process that entailed arrangements with both the sender (Universal Music Italy) and the post depot. A second scene cuts to a house interior where Massimo, his wife Daniela and their daughter Caterina open the parcel and examine its contents: the CCCP 1980s LP reprints about to be released as a $30^{\text {th }}$-anniversary tribute by Universal Music Italy. The handheld camera follows Massimo and family as they appraise enthusiastically the vinyl reissues, with Massimo fanning out the covers for his own pleasure and the benefit of the camera.

Sequence 3 (06:16-09:25) serves narratively as an anticipation of the presentday reunion of CSI and their compositional process, including the setting where this takes place. In the first scene, two observational shots follow Massimo, the singer Angela Baraldi and the guitarist Giorgio Canali entering the spaces of the Gualtieri Theatre. The camera is acknowledged verbally by Massimo and Angela, and, through a fleeting look into the lens, by Giorgio. Massimo shows the others around in the theatre. The open space of the orchestra, he suggests, is where the band will be seated in circle with "the enemy" in the centre. In response to Angela's inquiry Massimo clarifies that The Enemy is the title of the song that the band will be working on. A closing shot of the drummer Simone Filippi setting up amp cables is overlaid by the non-diegetic incipit of Emilia paranoica (Paranoid Emilia), an iconic CCCP song.

The next scene is set to the sound of this song, recorded at a concert held in Correggio on April $27^{\text {th }} 2013$ by Ex-CSI members, including Massimo, Angela, and Giorgio. Being the first live performance by the protagonists, I intended to break the ice by conveying in a nutshell something of the powerful sensuous engagement experienced by both musicians and audience on that and other live acts by CSI. To this end I opted for a cinematic representation quite removed from a realistic depiction of the action. While the live sound of the song goes on for about two minutes, the cuts utilized are a compendium of footage from disparate moments of the same concert and of material extrinsic to it. The 
scene opens with travel shots showing the hillsides of Reggio Emilia, and cuts to an establishing long shot of the musicians on stage and the audience. This is the only shot edited with synchronous sound. What follows is a montage of performance excerpts edited out-of-synch with the soundtrack and recurrently interpolated in slow motion. This process of aestheticization aims to magnify the musicians' bodily performance and trigger affective responses in the viewers, possibly bearing some affinity with the punk ethos of the music represented. The montaged footage is at once related to the live audio track (i.e. it belongs clearly to the same concert), and relatively unanchored from the pro-filmic event, at once denotative representation and metaphor. Likewise the sound straddles unstably the diegetic/non-diegetic divide. This perceptual ambiguity afforded the insertion of visual associations branching out of the concert, particularly flashback shots - taken from Gasparini's 1989 Tempi Moderni. CCCP Fedeli alla Linea - where a younger Massimo Zamboni performs with former CCCP-CSI singer and front man Giovanni Lindo Ferretti. This is the only instance in the film where archival footage is used as a memorial medium, whose "pronominal code" (MacDougall 1995: 223), as is often the case with archival materials, is here deliberately left uncertain: ${ }^{19}$ whose memory is being evoked, the musicians', the filmmaker's or, potentially, the viewer's? In one of these cuts, Ferretti's lips are made to move in synch with Baraldi's vocals in the music recording, signalling both Ferretti's legacy and his substitution. The music here is at once a memorial device - the song being an aural icon of the history of CCCP, a "sign of resemblance" in MacDougall's terms $(1992,31)$ - and representation of the present as ethnographic site and locus of remediation of the past.

Sequence 4 (09:25-15:22) cuts to an interior scene where Massimo pulls out from a cabinet newspaper articles, flyers, photographs, and other memorabilia from the early days of CCCP. These objects function as "signs of survival" of the past (MacDougall, 1992, 30-31). They are not injected into the text from an extrinsic subjectivity - as would be the case with archival images - but handled by the protagonist as part of the flow of his recollection. Massimo recounts some episodes of the CCCP trajectory, including his first meeting with Ferretti in Berlin; their first controversial performances, where the enmeshing of Soviet symbolism and punk aesthetics along the fault-lines of irony and ideological orthodoxy attracted mixed responses; their final concert in Moscow before the Red Army and the eventual breakup of the band after the fall of the Berlin Wall. Massimo offers insights into the existential tension that propelled his music making: this was for him a "weapon to cultivate a life" of his own - a suggestive analogy with the Resistenza partisans - and a means to "come to terms" with the history of Reggio Emilia as a long-standing communist hub. The scene establishes

${ }^{19}$ See MacDougall, 1992, 30, 35. 
Massimo's first-person testimony as the leading mode of subjectivity structuring in the film..$^{20} \mathrm{~A}$ mobile and participatory handheld camerawork eschews the distancing of a formal interview and follows Massimo's storytelling and bodily engagement with objects and space - an observational representational strategy already introduced in Sequence 1 and adopted repeatedly throughout the film. In closing, Massimo pulls out the lyrics of the CCCP song Spara Juri (Shoot, Juri!), and realizes with surprise that among the lyrics he is dusting off from the shelves there are unpublished "treasures" that would be worth retrieving for the future.

The next scene shows the performance of Spara Juri from the same concert of Sequence 3. Here the representational approach is of the kind typical of the American direct cinema tradition, including its rockumentary strand. ${ }^{21}$ Long takes of handheld camerawork capture the performance in temporal and spatial continuity, following the action through variations of focal length and switching moderately between two camera angles. This approach allowed the attention to be kept squarely on the song and its illustrative role in the CCCP storyline.

Sequence 5 (15:22-20:05) begins with an extended audio lead of Massimo's voice on the preceding concert scene. The voice turns onscreen as he, framed in an interview static shot, recounts how CSI were born out of the remnants of CCCP and were active throughout the 1990s. Due to harsh contrasts in the band, CSI too came to an end, but now, fifteen years after, they "are slowly coming together again." The camera cuts to a participatory handheld shot where Massimo points each band member on a CSI photograph hung on the wall. He announces a little "coup de theatre" and removes from the photo the sticker covering his face that he had put on after the band's breakup.

Having in this way launched the theme of the band's reunion, the next scene continues in a rather expository way: over the images and the diegetic sound of Post-CSI setting up their gear in the Gualtieri Theatre, Massimo's voiceover relates how he involved the other members in the Partisan Hymnbook project. Angela Baraldi and Massimo are shown interacting while Massimo narrates that they have been collaborating for a while and she has eventually taken over Ferretti's role as Post-CSI vocalist. Next, two reverse sideways tracking-shots across the 180-degree axis show from a distance Post-CSI at work in the theatre orchestra.

The following scene features pit music from the Baraldi and Zamboni song Vorremmo esserci. A series of steadicam shots meander through the run-down, vacant balconies and backstage areas of the theatre and follow Angela in a patently staged stroll about the premises. This stylized progression leads to a sudden change of setting, achieved through a formal editing tactic exploiting the consonance of colour temperature between two disparate images: while the pit

\footnotetext{
${ }^{20}$ See MacDougall, 1995, 226-228.

${ }^{21}$ See Beattie, 2008, 70f.; Grimshaw and Ravetz, 2009, $20 f$.
} 
music continues, the camera now captures Massimo walking uphill in a floodlit forest - an anticipation of the next scene.

Sequences 6 to 8. This chapter is dedicated to the place of the Second World War antifascist Resistenza in the experience and thought of Massimo Zamboni, as well as in the musical trajectory of CSI and Post-CSI.

Sequence 6 (20:05-23:11) opens with Massimo fetching chopped wood for a stove in a rural house. Two outdoor shots follow Massimo walking near the house. He recounts that he and his family moved there twenty years earlier. During Second World War, the house served as a partisan shelter and the forest behind it as a hideout for weapons. Foregrounded here is the connection between the partisan experience - and the memory of it - and specific material places. This connection is to be evoked recurrently in the film, mostly through what David MacDougall calls "signs of absence" (1992, 32): landscapes captured in the present referencing the past through its absence, and calling upon the viewer's imagination to fill in the gaps and conjure up a world hidden away from representation.

Next is an indoor scene where the participatory handheld camera captures Massimo pulling out from a shelf the book of the 1995 Materiale Resistente (Resistant Material) project. Conceived for the $50^{\text {th }}$ anniversary of Italy's liberation from Nazi-fascism, this project achieved nationwide resonance. It included a book, a documentary film (Materiale Resistente, 1995), a concert, and a CD in which some of the prominent indie bands of the 1990s reinterpreted historic partisan songs or wrote new songs on the theme. Massimo looks back to the leading role of CSI in this project and their commitment to the memory and renovation of the antifascist struggle. Massimo further reflects on how post-war Italy has "coddled" the memory of fascism, failing to confront its history.

Sequence 7 (23:11-31:47) is bookended by the Resistenza-themed song Guardali negli Occhi (Look them in the eye), CSI's contribution to the Materiale Resistente album. It opens with a staged steadicam shot of Gianni Maroccolo playing solo the song's bass line in the Gualteri Theatre. The music becomes non-diegetic as the hazy, dreary landscape of the film's opening, including the ominous cross, is shown in glimpses. The camera cuts to the Post-CSI performance of the song at a live concert, captured through stationary long shots from afar, and handheld shots from up close. As the live music progresses this observational depiction is replaced by a series of close-ups of partisan photographs from the Resistenza monument in the city of Reggio Emilia. In the next scene, Massimo approaches the monument and inspects the photographs. In front of the interactive camera he explains that Guardali negli occhi was a response to the daunting interpellation emanating from precisely these partisan portraits, whose gaze "is difficult to hold." Referring to the writings of Beppe 
Fenoglio ${ }^{22}$, it is the existential dimension, the individual morality, and the drive to self-defence and rebellion as a matter of "private concern" rather than grand ideological proclamation, that - Massimo ponders - make the partisans' choice to risk their lives at once terrifying and inspiring. Delivering a central trope of the film, he points out what startles him as the most "difficult knot to untangle" about the civil war: that the partisans and the fascists, "the oppressed and the oppressors" who stood on opposite sides of the right/wrong divide of history, belonged to the same land and the same people, confounding any clear notion of the enemy as "the other" and making it "our duty to understand the complexity of the matter."

Next comes the first of a number of carefully designed, staged scenes interspersed in the film, in which Massimo reads from his book sitting in the Gualtieri Theatre. A tracking shot, moving forward and backwards, reveals the dolly rail and exposes the mise-en-scène. Massimo's reading offers a metacommentary to the partisan song Il bersagliere ha cento penne (The Rifleman Has One Hundred Feathers), whose reinterpretation forms the closing section of CSI's Guardali negli occhi. Lastly, the camera cuts to the live performance of this closing section from the same Post-CSI concert shown earlier in the sequence.

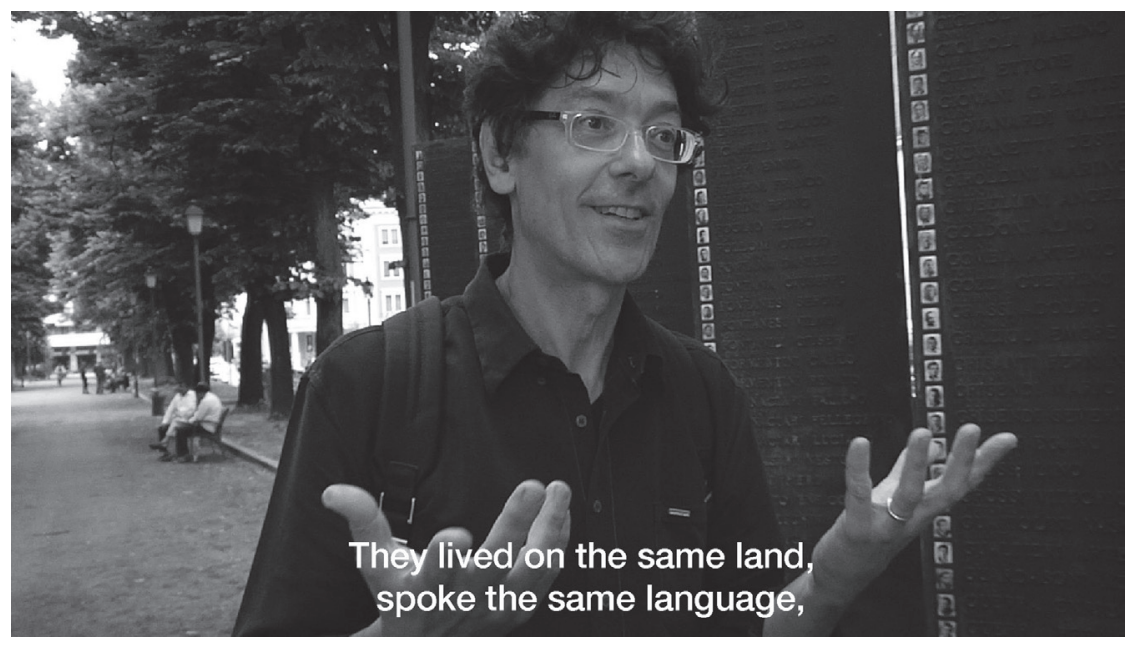

Figure 3. Massimo Zamboni at the Resistenza monument in Reggio Emilia. Still frame from the film. (Il Nemico - un breviario partigiano, 2015)

${ }^{22}$ Having himself fought as a partisan, Fenoglio's nonfiction novels (notably Fenoglio, 1952, 1963, 1968) are among the classics of Resistenza literature. 
Sequence 8 (31:47-37:23) begins with a transition between two images of Angela Baraldi - first on stage and then in the Gualtieri Theatre. After an establishing shot, the scene features two handheld cameras to capture observationally (albeit selectively) the band's compositional work on the song Il nemico, occasionally using shots/reverse-shots to follow their conversations. The intention here was to minimize the musicians' interaction with the camera and focus on their collaborative dynamics.

Next is an interview featuring static shots of Massimo sitting in a decrepit backstage room of the theatre. This setting will be employed again for Massimo's commentary on the ongoing Post-CSI compositional process. It is a challenge to bring together musicians who, he feels, have "conflicting ideas" regarding the Partisan Hymnbook project. He goes on to elucidate the symbolic significance of composing a song in the Gualtieri Theatre. Rescued from ruin by the efforts of a community association, the theatre is a metaphor for Post-CSI's task: choosing between forgetting the Resistenza, or delving once more into the meaning it has "today for the life of each one of us."

Sequences 9 to 11 . This chapter uncovers the specifics of Zamboni's research of his family history. It is deliberately placed halfway through the overall narrative for dramatic effect: while up to this point Massimo has been depicted as an artist committed to antifascism, this perspective is here problematized: Massimo has discovered that his family had close ties with fascism.

Sequence 9 (37:23-41:43) opens with Massimo at the gates of a rural mansion, calling the landlord on his cellphone for permission to film. He then leads the camera inside the mansion. He finally reveals that this was his maternal grandfather's house, to which his grandfather never returned. Massimo recalls spending his summers here as a child, but his voice is broken with emotion.

The next scene relates back to the locations of the film's beginning, and finally unpacks some of the oblique hints provided there. It opens with the sinister cross, followed by a desolate Po valley landscape in the winter twilight. Over pit music of slow-pulsing piano chords, Massimo reads off-screen from his book. He recounts how his grandfather was ambushed and fatally struck down by a gunshot in February 1944. Mirroring the setting of Massimo's story, the camera moves along a country trail flanked by a ditch - visuals that function as memory signs of both resemblance and absence. Massimo's voice becomes diegetic as he is shown reading into the microphone, thus revealing the mise-en-scène. ${ }^{23}$ In what follows, the camera cuts back and forth between tracking shots of misty fields and poplar forests, and Massimo onscreen at his desk, continuing the recording of his reading and, then, speaking to the participating camera. The sound

${ }^{23}$ This musicalized reading by Massimo was eventually included as a track on the Partisan Hymnbook CD release. 
interweaves Massimo's off-screen/onscreen voice with the landscape's rustling leaves and the non-diegetic bass line of Linea Gotica (recaptured from the film's opening). Massimo narrates that his grandfather was a committed fascist, who had important responsibilities in Mussolini's political apparatus, and that his assailants were partisans. A long-kept secret of his family, Massimo knew very little about his grandfather's involvement in fascism until he began "to rummage in private notes and archive documents." This research went into his book, he remarks while browsing the book's manuscript.

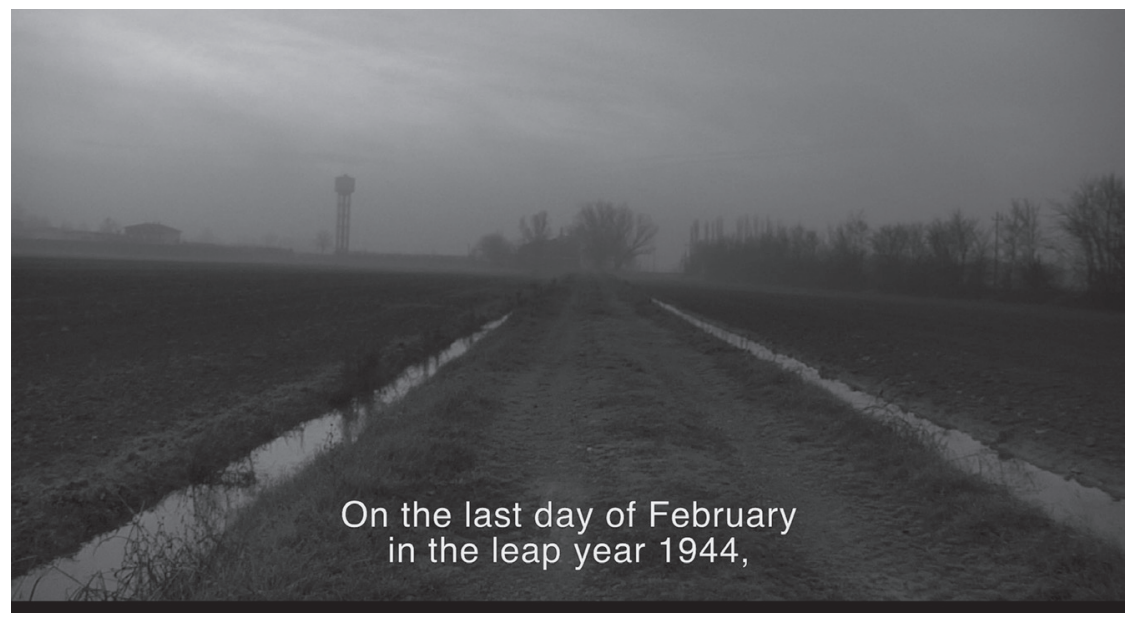

Figure 4. The camera moves along a country trail visualizing Zamboni's off-screen reading from his book. Still frame from the film. (Il Nemico - un breviario partigiano, 2015)

Sequence 10 (41:43-46:23) begins in the premises of Reggio Emilia's ISTORECO with historian Massimo Storchi browsing archive documents. $\mathrm{He}$ hands over to Massimo a partisan report indicting Massimo's maternal grandfather, and the fascist brigade of which he was part, for a brutal assault against unarmed citizens. Massimo recalls how troubled he was when he first came across this report, which undermined the image he had of his family and of his own background. Here as in most of the film, Massimo's research is retraced through his own reminiscence. Instead, the subsequent shots capture in real time Massimo's unforeseen discovery of a document that, to his dismay, implicates also his paternal grandfather in the fascist regime. 
Breaking out from Massimo's disquieting new finding, the camera cuts to a live performance of the Zamboni-Baraldi song In Rotta (Derailed), an unforgiving portrayal of Italy as a country in disarray and of Italians as a "mad brethren". GoPro lenses give the visuals the hyperbolic quality of an inner vision, reinforced by the intercutting of disorienting, non-literal landscapes, including feverish subjectives in a forest and high-angle shots of a flooded countryside. As the music fades out, a man takes a globe out of its display case in what appears to be a museum.

Sequence 11 (46:23-51:58) opens with another reading from Massimo's book in the Gualtieri Theatre, staged as in Sequence 7. In 1941 Massimo's maternal grandfather was appointed fascist official in the stubbornly socialist and antifascist municipality of Campegine, where the Cervi family in particular was known to be untameable. In the next scene the camera cuts to the museumhouse of the Cervi family, where curator Mirco Zanoni has mounted the globe on a tractor: these two objects, he explains, stand for the openness to the world and the belief in progress and change that characterized this peasant family. Zanoni illustrates some of the antifascist, revolutionary activities undertaken by the Cervis, including the setting up of a clandestine library for the farmers. The seven Cervi brothers were possibly the first to rise up to armed revolt against fascism in 1943 and the first to be massacred by the fascists in the course of the Resistenza - facts that made them into a most exemplary symbol of the Resistenza in post-war Italy.

Massimo now circles the outer wall of the Cervi house. His voiceover narrates from his book that one day the Cervis, together with a company of traveling actors, organized a theatre play to secretly raise funds to arm the partisans. Massimo's grandfather was in the audience and donated money to the actors in appreciation of their performance, in this way paying indirectly for the gun that would eventually kill him. Next, the participatory camera captures Massimo outside the Cervi house as he explains that, while the gunshot was the starting point of his research, he ended up digging into two centuries of his family's history in order to understand what might have led to it. Massimo's forebears rose to great wealth over the generations and came to own several farming estates and palaces in the Reggio Emilia province. Part of the landowning bourgeoisie, their adherence to fascism was resolute and self-serving. It is easy for Massimo to blame them, but he wonders to himself whether in the same conditions he would have done any better. 


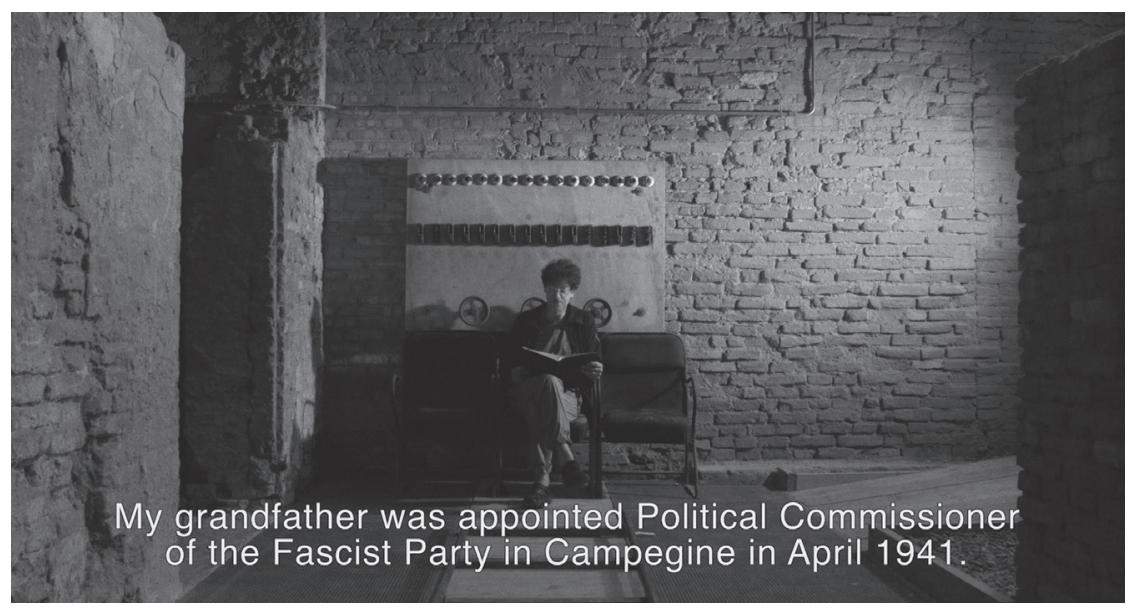

Figure 5. Staged scene of Massimo Zamboni reading from his book in the Gualtieri Theatre. Still frame from the film. (Il Nemico - un breviario partigiano, 2015)

Sequences 12 to 14 . This chapter addresses the contested nature of the memory of the civil war. It concerns itself with literary and historiographical sources, as well as with further developments in Massimo's and Post-CSI's work.

Sequence 12 (51:58-1:01:45) opens by underscoring Massimo's thoughtprovoking words in the preceding scene. Angela Baraldi performs a staged reading of Pavese's passage quoted at the beginning of this article. The visuals intercut tracking shots of the majestic interior of the Gualtieri Theatre where Post-CSI are at work, with mounted-camera shots of Angela holding a manuscript in a backstage room. Her onscreen/off-screen voice gradually intermingles with the band's music.

The next scene features an interview with Massimo shot as in Sequence 8 . Massimo comments on the compositional work of the day before, and reports that a heated discussion over dinner brought up deep contrasts in the band's understanding of their task and the meaning of the Resistenza. He lets out his frustration and casts doubts on the success of their reunion, but also declares his intention to persevere in the work. Today is a new day.

Back in the theatre orchestra, the handheld camera follows the next step of the band's compositional process. A few miscommunications and disagreements among the musicians as to form and harmonic solutions are put in relief, but it is clear that a song is gradually taking shape. This observational scene is intercut with two excerpts of static interviews with the CSI members Francesco Magnelli and Gianni Maroccolo, who comment on the work being undertaken. A lengthier interview with Giorgio Canali illuminates the contrasts harbouring within the 
band: Giorgio believes, in contrast with Massimo, that the Resistenza discourse has lost vitality and should be reignited through a more seditious vocabulary. $\mathrm{He}$ suggests that the "violent and highly symbolic event" of Mussolini's execution be celebrated in place of Italy's Liberation Day. This is a crucial narrative juncture that positions Giorgio and Massimo as proponents of competing views. In what is my sole (off-screen) appearance in the film, I ask Giorgio whether he would share with the band his song Lettera del compagno Laszlo al colonnello Valerio (Letter from Comrade Laszlo to Colonel Valerio), an option he refuses because that song represents his own personal views.

The next scene portrays in one sequence-shot Giorgio's solo performance of the song, delivered in the Gualtieri Theatre for the purposes of the film. An imaginary letter from a partisan to his commander, the song recaptures the timehonoured theme of the "betrayed Resistenza", pointing the finger with fiery tones at the survival of fascism in post-war Italy. It regrets that with the premature end of the armed struggle many partisans died in vain and voices a desperate yearning to continue the killing of fascists. The inclusion of this incendiary song in the film was quite problematic. The song had previously been rejected by publishers allegedly due to a line containing blasphemous swearing - but there are good reasons to suspect that the song's overall content too was a matter of concern. It was eventually released independently by Canali in 2010 and achieved cult status particularly among militant antifascists. During the postproduction of the film it became apparent that some of our distribution channels would have backed out had we retained the song in its entirety. On the other hand, I deemed it important to feature it in the film, for it offers a reflection of ethnographic and political significance in the context of contemporary musical memorializations and the larger Resistenza discourse in Italy. I had to juggle an ethically and politically delicate negotiation between different constituencies, including the songwriter, the distributors, the prospective public and myself as author. However reluctantly, Giorgio Canali and I agreed that cutting out the blasphemous lines would not undermine the point of the song. As a result, we crafted two versions of the scene: a censored one (for the most official distribution venues, including the DVD and movie theatres) and the uncut one. 


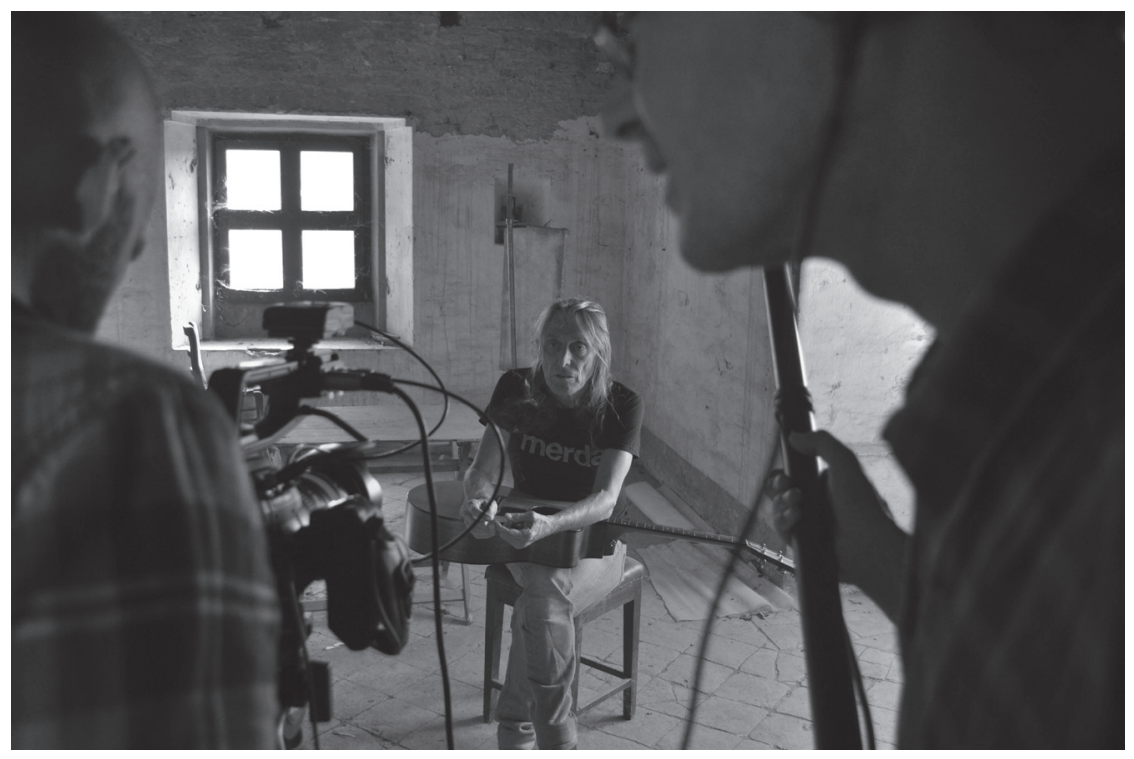

Figure 6. Setting up the interview with Giorgio Canali. (Fantetti, 2014)

Sequence 13 (1:01:45-1:08:54) opens with an interview of historian Massimo Storchi in his office. The authoritative testimony of historiography is utilized and, concurrently, relativized as an ongoing debate through meta-discursive references as the interviewee reads from and comments on his own writings and those of historian Giovanni De Luna. (Storchi, 2009, 20; De Luna, 2006, 186) Storchi highlights the continuity between the fascist state apparatus and the newly born Italian republic. Some historians have even interpreted Italy's post-war institutional discourse about the Resistenza as a "self-absolving alibi" to cleanse the nation of its past and present collusions with fascism. Launching the narrative development coming next in the film, he goes on to report how toward the end of the war the Nazi German occupying forces and the Italian fascists increasingly targeted partisans in the province of Reggio Emilia, stirring up deep resentment and vengeance.

What follows is a composite scene that alternates in parallel editing Massimo's staged book reading in the Gualtieri Theatre, and the rural location of the film's opening, whose identity is finally clarified. Massimo tells of the bulldozers that, across the Reggio Emilia plains, have been seeking the spoils of fascists killed in secret in the immediate aftermath of the war - a relentless search engaged decades after by their relatives. Shots of the dreary landscape of the film's beginning, including the cross, are overlaid by the pit-music refrain of Linea Gotica. The camera lingers on the pond. It then shows Massimo walking towards 
it, surrounded by what has now become lush springtime vegetation (mirroring a passage of this narration). Massimo reveals that the pond is a flooded sand pit outside the village of Campagnola Emilia, where the remains of 19 fascists were dug out fifty years later. Now in situ before the participatory handheld camera, he marvels at the perseverance of this search and ponders the relative benefits of memory and oblivion, drawing an implicit parallel to his own digging into his family's past. It was his aversion to the greediness and ruthlessness of the powerful - he remarks in a closing onscreen book reading - that drove him to antifascism, therefore disowning his family background and siding with "the enemy."

Sequence 14 (1:08:54-1:14:07) depicts in the Gualtieri Theatre the performance of Il nemico, Post-CSI's newly composed song. It is a single scene that combines, into one seemingly continuous performance, steadicam, tracking and crane shots actually drawn from three different performance sessions and synchronized in postproduction with the song's reworked sound recording. This stylized representational strategy aims to coronate the band's accomplishment after its internal rifts have been emphasized in the film's narrative. Set up finally as a process of encounter and mutual understanding, Post-CSI's music making is here meant to figuratively stand for broader possibilities of bridging conflicts in memory discourse and achieving accord through common work. ${ }^{24}$

Sequence 15 (1:14:07-1:20:45) brings the film to a somewhat open-ended close. It focuses on Massimo's work in progress on another new song, entitled Breviario partigiano. After arriving by car to a rural location, Massimo sets up his equipment and tries out a few passages of the song in a recording studio. He and Post-CSI drummer Simone Filippi are then shown attending to the song recording at the mixer. A rough cut of the song is heard on the air. ${ }^{25}$ The camera cuts to a different interior location. It captures glimpses of the rehearsal of an acoustic ensemble of horns, strings and percussions, with conductor Emanuele Reverberi imparting instructions to the musicians. A stationary long shot from behind Massimo's and Filippi's backs shows them at a portable mixer desk waiting for Reverberi and his ensemble to start the recording. The camera cuts in to focus on the ensemble. After an initial false start, they play a section of Breviario partigiano. As the performance gains momentum the end credits begin to crawl.

${ }^{24}$ Tell me mother - is our toil just or only painful?/Will it extinguish the lamenting?/Tell me father - will the new day bring forgiveness?/Or will it only bring torment?/The enemy has broken into my city.

${ }^{25}$ Partisan hymnbook - I have no rifle with me/But only true innocence to travel against the current./Partisan hymnbook - I have no rifle with me./But the usual incoherence that will carry us forward. 


\section{References}

And The Mountains Float Up Like Feathers, 2013. [Film] Directed by Federico Spinetti. Italy: Lab80Film.

Araújo, S. and members of the Grupo Musicultura, 2006. Conflict and Violence as Theoretical Tools in Present-Day Ethnomusicology: Notes on a Dialogic Ethnography of Sound Practices in Rio de Janeiro. Ethnomusicology, 50/2, 287-313.

Austin, J., 1999. How to Do Things with Words. Oxford: Clarendon Press.

Assmann, A., 2009. Erinnerungsräume: Formen und Wandlungen des kulturellen Gedächtnisses. Munich: Beck.

Baily, J., 1989. Filmmaking as Musical Ethnography. The World of Music, 31/3, 3-20.

Baily, J., 2009. The Art of the "Fieldwork Movie": 35 Years of Making Ethnomusicological Films. Ethnomusicology Forum, Vol. 18/1, 55-64.

Baker, C., 2009. War Memory and Musical Tradition: Commemorating Croatia's Homeland War through Popular Music and Rap in Eastern Slavonia. Journal of Contemporary European Studies, 17/1, 35-45.

Barbash, I. and Taylor, L., 1997. Cross-Cultural Filmmaking. A Handbook for Making Documentary and Ethnographic Films and Videos. Berkeley: University of California Press.

Beattie, K., 2008. Documentary display: re-viewing nonfiction film and video. London: Wallflower.

Bennett, A. and Janssen, S. eds., 2016. Popular Music and Society 39/1. Special Issue: Popular Music, Cultural Memory, and Heritage.

Bermani, C., 2003. Il nemico interno. Guerra civile e lotta di classe in Italia (19431976). Roma: Odradek.

Bithell, C., 2006. The Past in Music: Introduction. Ethnomusicology Forum, 15/1, 3-16.

Butler, J., 2004. Precarious Life: The Powers of Mourning and Violence. London; New York: Verso.

Butler, J., 2009. Frames of War: When Is Life Grievable? London, New York: Verso. Cámara de Landa, E., D’Amico L., Isolabella, M. N. and Yoshitaka, T. eds., 2016. Ethnomusicology and Audiovisual Communication. Selected Papers from the MusiCam 2014 Symposium. Valladolid: Universidad de Valladolid.

Carrère, E., 2011. Limonov. Paris: P.O.L.

Chion, M., 1994. Audio-vision: Sound on Screen. New York: Columbia University Press.

Connerton, P., 1989. How Societies Remember. Cambridge: Cambridge University Press. 
De Luna, G., 2006. Il corpo del nemico ucciso: violenza e morte nella guerra contemporanea. Torino: Einaudi.

Elder, S., 1995. Collaborative Filmmaking: An Open Space for Making Meaning, A Moral Ground for Ethnographic Film. Visual Anthropology Review, 11/2, 94-101.

Erll, A. and Nünning A. eds., 2008. Cultural Memory Studies: An International and Interdisciplinary Handbook. Berlin; New York: De Gruyter.

Erll, A. and Rigney A. eds., 2009. Mediation, Remediation, and the Dynamics of Cultural Memory. Berlin: Walter de Gruyter.

Fantetti, L., 2014. Filming Post-CSI at work in the Gualtieri Theatre. [photograph] Personal collection of F. Spinetti.

Fantetti, L., 2014. Setting up the interview with Giorgio Canali. [photograph] Personal collection of F. Spinetti.

Feld, S., 1976. Ethnomusicology and Visual Communication. Ethnomusicology, 20/2, 293-325.

Fenoglio, B., 1952. I ventitré giorni della città di Alba. Torino: Einaudi.

Fenoglio, B., 1963. Una questione privata. Milano: Garzanti.

Fenoglio, B., 1968. Il partigiano Johnny. Torino: Einaudi.

Focardi, F., 2005. La guerra della memoria. La Resistenza nel dibattito politico italiano dal 1945 a oggi. Bari: Laterza.

Grimshaw, A. and Ravetz, A., 2009. Observational cinema: anthropology, film, and the exploration of social life. Bloomington: Indiana University Press.

Hardt, M. and Negri, A., 2000. Empire. Cambridge, MA and London: Harvard University Press.

Hofman, A., 2015. Music, Affect and Memory Politics in Post-Yugoslav space. [Introduction to the special issue] Southeastern Europe, 39/2, 145-164.

Il Nemico - un breviario partigiano, 2015. [Film] Directed by Federico Spinetti. Italy: Lab80Film.

Johnson, B. and Cloonan, M., 2009. Dark Side of the Tune: Popular Music and Violence. Burlington, VT: Ashgate.

Kirkby, M., 1987. A Formalist Theatre. Philadelphia: University of Pennsylvania Press.

Luzzatto, S., 2004. La crisi dell'antifascismo. Torino: Einaudi.

MacDougall, D., 1992. Films of Memory. Visual Anthropology Review, 8/1, 29-37. MacDougall, D., 1995. The Subjective Voice in Ethnographic Film. In: L. Devereaux and R. Hillman, eds. Fields of Vision: Essays in Film Studies, Visual Anthropology, and Photography. Berkeley: University of California Press. 217255.

MacDougall, D., 1998. Visual Anthropology and the Ways of Knowing. In: L. Taylor, ed. Transcultural Cinema. Princeton, NJ: Princeton University Press. 61-92. 
Materiale Resistente, 1995. [Film] Directed by Guido Chiesa and Davide Ferrario. Italy: Dinosaura.

Mattioli, A., 2010. "Viva Mussolini!" Die Aufwertung des Faschismus im Italien Berlusconis. Paderborn: Ferdinand Schöningh.

McDonald, D., 2009. Poetics and the Performance of Violence in Israel/Palestine. Ethnomusicology, 53/1, 58-85.

Momcilovic, D. ed., 2011. Resounding Pasts: Essays in Literature, Popular Music and Cultural Memory. Newcastle: Cambridge Scholars.

Nichols, B., 1991. Representing Reality: Issues and Concepts in Documentary. Bloomington: Indiana University Press.

Nichols, B., 2001. Introduction to Documentary. Bloomington: Indiana University Press.

O'Connell, John and Castelo-Branco, S. E. eds., 2010. Music and Conflict. Chicago: University of Illinois Press.

Pavese, C., 2008. La casa in collina. Torino: Einaudi.

Pavone, C., 1991. Una guerra civile. Saggio storico sulla moralità nella Resistenza. Torino: Bollati Boringhieri.

Pettan, S. ed., 1998. Music, Politics, and War: Views from Croatia. Zagreb: Institute of Ethnology and Folklore Research.

Pettan, S. and Titon, J. T. eds., 2015. The Oxford Handbook of Applied Ethnomusicology. Oxford, New York: Oxford University Press.

Post-CSI, 2015. Breviario Partigiano 1945-2015 / Il Nemico - Un breviario partigiano. Un film di Federico Spinetti. [CD/DVD] S. 1: Tannen Records/ Universal Music Italia and Lab80film.

Romitelli, V., 2007. L'odio per i partigiani: come e perché contrastarlo. Napoli: Cronopio.

Romitelli, V., 2015. La felicità dei partigiani e la nostra: organizzarsi per bande. Napoli: Cronopio.

Rossi, A., 2015. "Il Nemico - un breviario partigiano" poster. [film poster] Personal collection of F. Spinetti.

Ruby, J., 1991. Speaking For, Speaking About, Speaking With, or Speaking Alongside - An Anthropological and Documentary Dilemma. Visual Anthropology Review, 7/2, 50-66.

Shelemay, K. K., 1998. Let Jasmine Rain Down: Song and Remembrance among Syrian Jews. Chicago and London: University of Chicago Press.

Storchi, M., 2007. Post war violence in Italy: a struggle for memory. Modern Italy. Journal of the Association for the Study of Modern Italy, 12/2, 237-250.

Storchi, M., 2008. Il sangue dei vincitori. Saggio sui crimini fascisti e i processi del dopoguerra (1945-46). Reggio Emilia: Alberti.

Tempi Moderni. CCCP Fedeli alla Linea, 1989. [Film] Directed by Luca Gasparini. Italy: Transtv. 
Thompson, M. and Biddle I. eds., 2013. Sound, Music, Affect: Theorizing Sonic Experience. New York; London: Bloomsbury.

Turino, T., 1999. Signs of imagination, identity, and experience: a Peircian semiotic theory for music. Ethnomusicology, 43/2, 221-55.

Whitehead, A., 2009. Memory. London, New York: Routledge.

Zamboni, M. 2015. L'eco di uno sparo. Torino: Einaudi.

Zemp, H., 1988. Filming Music and Looking at Music Films. Ethnomusicology, 32/3, 393-427.

Zurkhaneh - The House of Strength. Music and Martial Arts of Iran, 2011. [Film] Directed by Federico Spinetti. Canada, Italy: University of Alberta and Lab80Film. 